\title{
1: 153641739-153623738
}

National Cancer Institute

\section{Source}

National Cancer Institute. 1:153641739-153623738. NCI Thesaurus. Code C44969.

Physical location of INSRR_Gene 